\title{
Correction to: Potential reverse spillover of infectious bursal disease virus at the interface of commercial poultry and wild birds
}

\author{
Rania F. El Naggar ${ }^{1} \cdot$ Mohammed A. Rohaim ${ }^{2} \cdot$ Muhammad Munir $^{3}(0$
}

Published online: 30 January 2021

(c) The Author(s) 2021

\section{Correction to: Virus Genes (2020) 56:705-711 \\ https://doi.org/10.1007/s11262-020-01793-x}

The original version of this article unfortunately contained an error in figure.

Figures 1 and 2 have interchanged their positions in the article. The correct Figs. 1 and 2 are presented here.

The original article has been corrected.

Rania F. El Naggar and Mohammed A. Rohaim have contributed equally.

The original article can be found online at https://doi.org/10.1007/ s11262-020-01793-x.

Muhammad Munir

muhammad.munir@lancaster.ac.uk

1 Department of Virology, Faculty of Veterinary Medicine, University of Sadat City, Sadat 32897, Egypt

2 Department of Virology, Faculty of Veterinary Medicine, Cairo University, Giza 12211, Egypt

3 Division of Biomedical and Life Science, Lancaster University, Lancaster LA1 4YG, Lancashire, UK 

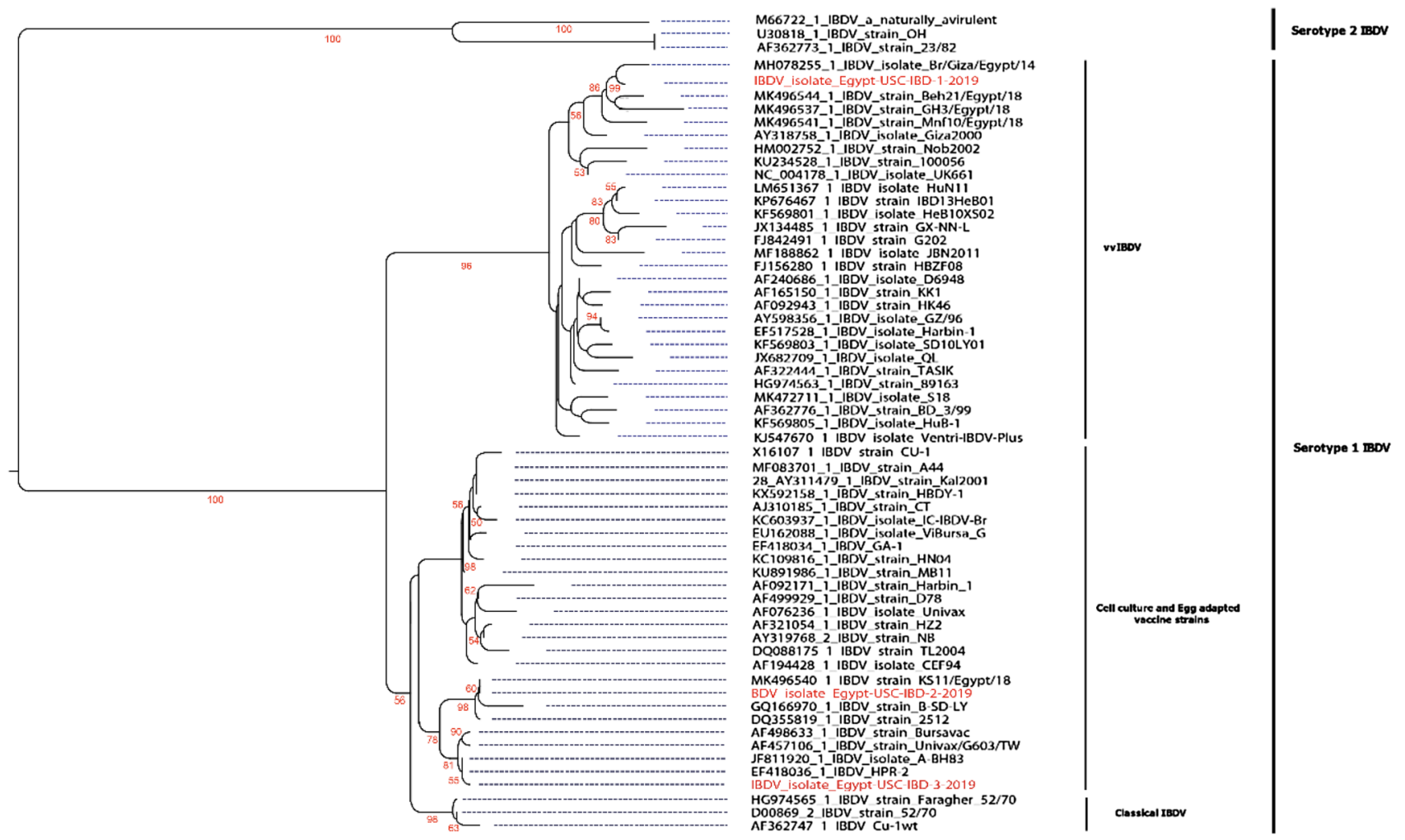

0.01

Fig. 1 Phylogenetic analysis of studied isolates and their clustering patterns with representative IBDVs. Full length VP2 gene based phylogenetic analysis of three wild-bird origin IBDV isolates with representative strains of currently circulating IBDVs in Egypt. One of the reported isolates clustered within vvIBDVs with close relationship with the previously characterized strains from commercial poultry while the other one clustered vaccine strains. The reported isolated marked with red colour 
(a)

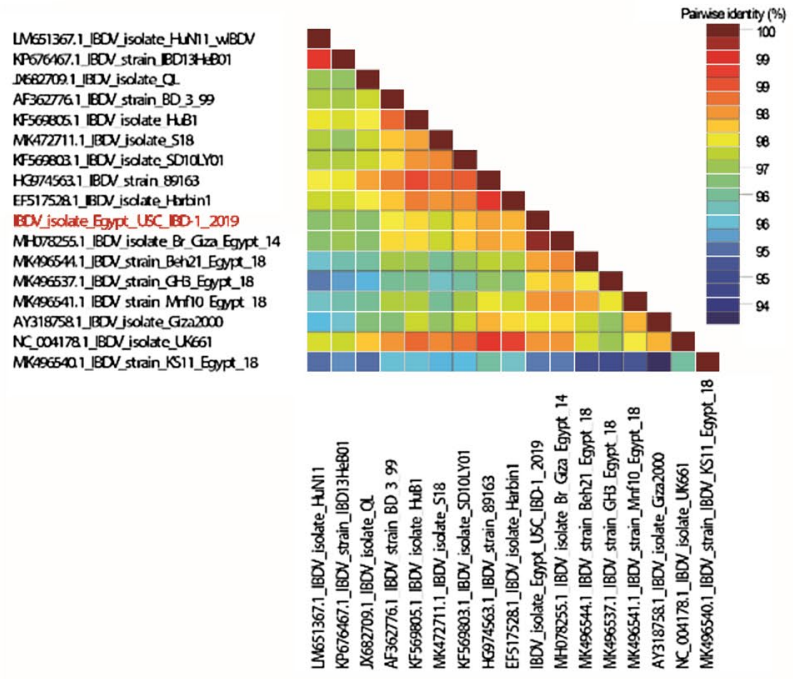

(c)

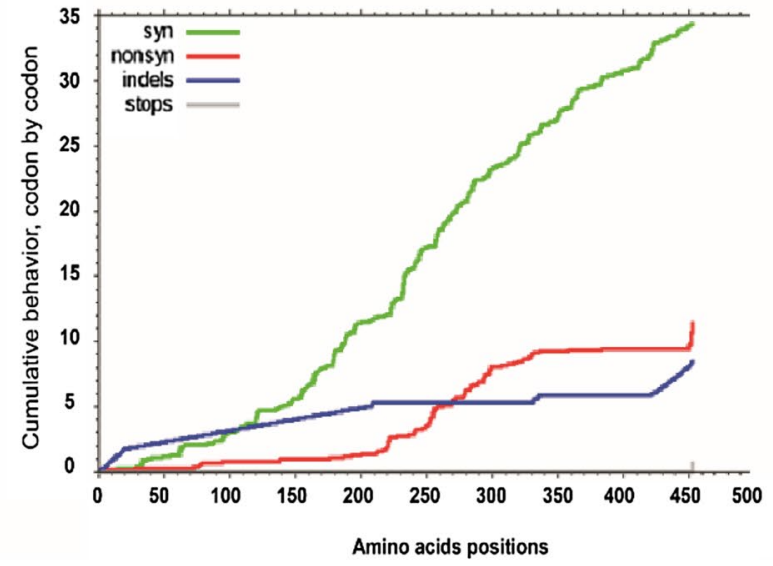

Fig. 2 Pairwise identity, localization of specific mutations in the VP2 protein of the newly identified vvIBDV strain and IBDVs selective pressure. The pairwise identities plot of VP2 gene for a Egypt-USCIBD-1-2019 compared to vvIBDVs and b Egypt-USC-IBD-2-2019 and Egypt-USC-IBD-3-2019 compared to IBDV vaccine-like strains aligned by ClustalW and displayed by Sequence Demarcation Tool

Open Access This article is licensed under a Creative Commons Attribution 4.0 International License, which permits use, sharing, adaptation, distribution and reproduction in any medium or format, as long as you give appropriate credit to the original author(s) and the source, provide a link to the Creative Commons licence, and indicate if changes were made. The images or other third party material in this article are included in the article's Creative Commons licence, unless indicated otherwise in a credit line to the material. If material is not included in (b)

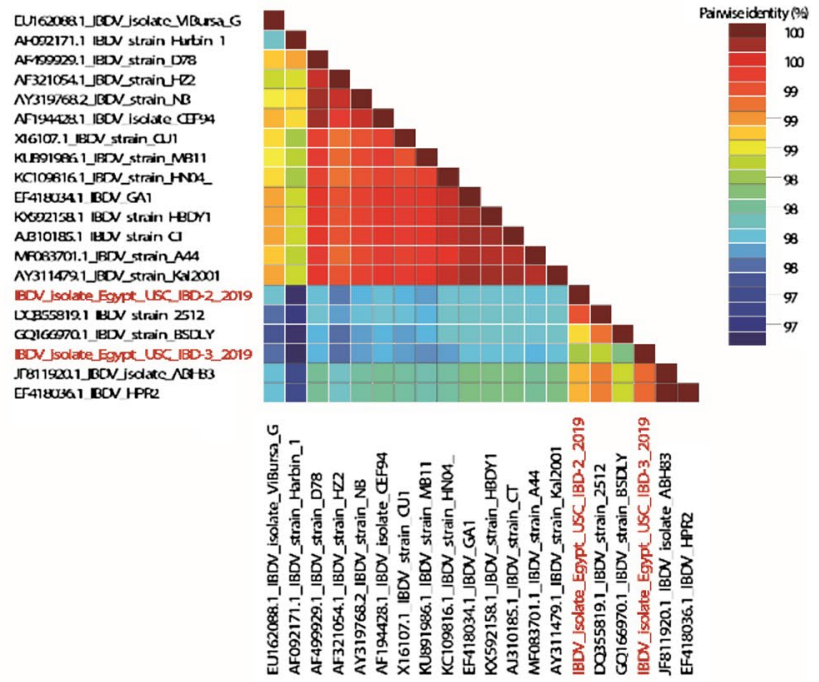

(d)

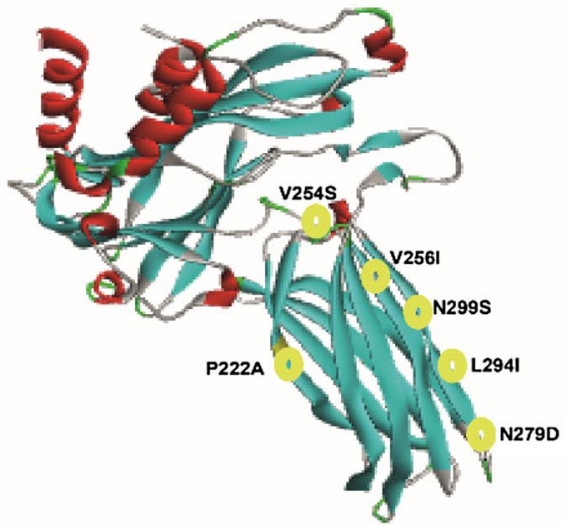

IBDV isolate Egypt-USC-IBD-1-2019

(SDT) software. $\mathbf{c}$ Cumulative behaviour of the average synonymous and non-synonymous substitutions moving codon by codon across VP2 gene. d 3D structure template for IBDV isolate IBDV/USC$3 / 2019$ showed the localization of specific mutations in the VP2 protein for IBDV isolate IBDV/USC-1/2019. The 3D was visualized by PyMOL software

the article's Creative Commons licence and your intended use is not permitted by statutory regulation or exceeds the permitted use, you will need to obtain permission directly from the copyright holder. To view a copy of this licence, visit http://creativecommons.org/licenses/by/4.0/.

Publisher's Note Springer Nature remains neutral with regard to jurisdictional claims in published maps and institutional affiliations. 